\title{
Research on Necessity, Objective and Realization of Property Tax Reform of China
}

\author{
Yongfeng Zhao \\ Tianjin University, Tianjin, 300072, China
}

Keywords: Property tax reform, Land finance, Real estate

\begin{abstract}
A good tax policy of the real estate can improve the quality of the sustainable development of the property industry and increase the revenue of local finance. While low-quality policies impede local economic development and fiscal revenue. At present, the existing real estate tax policy in China has lagged behind the development of the real estate market. This paper analyzes the necessity and objective of the property tax reform in China, and gives the objective realization of enhancing informatization level of property tax collection, establishing evaluation mechanism of property tax price, strengthening publicity degree of property tax levy and extending pilot project of property tax reform to provide some references for the relative researchers.
\end{abstract}

\section{Introduction}

Because of the rapid development of the real estate industry in China, the house prices in our country have been high and even higher and higher [1]. This has seriously affected the development of China's national economy, making the gap between the rich and the poor in China increased. Relatively rich people will energetically invest in investing in buying a house, and many people can't afford to buy a house at all. The real estate tax reform can effectively alleviate this situation. At present, the new problems and new contradictions in the social and economic development of our country need to be solved in the comprehensive deepening of the reform. The reform of the property tax has become an important part of it, and the controversy it has caused is not only limited to the field of Finance and taxation, but also the transformation of the way of social management. In recent years, with the rapid rise of the value of real estate, a lot of investment and speculative demand has been generated besides the demand of rigid self-occupied housing, resulting in the increasing gap between the rich and the poor in society, which has a negative impact on social stability. After years of reform, great changes have taken place in the economic and social conditions in China, and the privatization of real estate has become an irreversible trend. In recent years, with the continuous improvement of the overall economic level of our country, the house price has gradually exceeded the scope that ordinary residents can bear. To curb housing prices continued to rise, reducing the residents to bear the economic pressure, China's central government according to the actual situation of China's real estate development, real estate industry for tax policy has made a series of adjustments, trying to make the existing property tax to the real estate industry rapid development request. However, as the development of the real estate industry is too rapid, the existing property tax policy cannot be well adjusted to the housing price and other aspects. In this paper, the necessity of the reform of the property tax in China and some problems in the reform of the property tax are discussed to promote the benign development of the local finance [2].

\section{Necessity of Property Tax Reform of China}

If we take the real estate industry and the construction industry as an important part of the national economy, these two are still the pillar industries of the national economy in the development of urbanization in the coming decades [3]. But the development of the real estate industry is in addition to the market track, there is also a basic guarantee track. These two must coordinate and co-ordinate 
in the market economy environment and jointly guide the healthy development of the real estate industry. Integration and optimization from land development links to real estate transactions, and then to the preservation of housing, etc., all taxes and fees in the whole process will be carried out with reasonable supporting reforms. The new policy of real estate regulation is still in contradiction after several years. To deal with this contradiction needs systematic system and policy of systematic geography. As an important source of national financial revenue, taxation plays an indispensable role in raising the state's financial revenue. Especially for the real estate industry, due to the rapid development of the real estate industry, and is an essential part of people's daily life, therefore, reforming the tax policy of the real estate industry will help to increase the revenue of the state and local governments. Due to the rapid development of the real estate industry in recent years, housing prices have been showing a rising trend, which is likely to lead to an imbalance in the economic market. Therefore, the reform of real estate tax will help to maintain the normal operation order of the economic market. A complete tax system is bound to include three kinds of comprehensive taxes, such as property tax, income tax and transfer tax. But now, as the main item of property tax, the real estate tax in China still lacks certain policy integrity in the development of domestic market economy, and it can match the economic market environment. Therefore, the reform of the property tax will help to improve the tax system in this industry.

\section{Objective of Property Tax Reform of China}

In terms of allocation and regulation function, the introduction of property tax can stimulate market resources to meet the housing needs of ordinary people, and then achieve the goal of more rational allocation of real estate resources among different classes, that is, the fair goal of society. The goal choice of the real estate tax reform cannot be carried out in isolation. We must closely relate to the reality of our country and consider the main contradictions and problems faced by the finance. That is, a scientific and feasible train of thought is: the key problem decides the goal of tax system reform, the goal of tax reform decides the basis of Taxation, and the basis of tax collection ultimately determines the design of tax system. The large income gap and the structure of the social stratum have become the key problems to be solved in the period of social transformation in China. Present social class structure compact, social resources is basic pioneer and elite group of the market, the winner of the logic is to play a role. In this historical background, as the government regulate the distribution of income, an important means of social justice, the moderating effect of property tax on how the social hot become a target for all. China's economic and social environment and the long-faced problems have determined that only the adjustment of income distribution is the primary goal of the reform of property tax. The property tax should clarify the target location, highlight the role of adjusting the income distribution, formulate the basic tax system of the property tax, guarantee the tax burden to meet the requirements of horizontal equity and vertical justice. Only by narrowing the gap between the rich and the poor can the masses support the reform of the tax system, and the other goals can only be considered. Only by placing the reform of property tax in the sharp contradiction of income distribution in China, the reform of real estate tax can be widely supported by the people. The special transmission mechanism of real estate tax plays an important role in the multi-level and multi-level tax control system in China [4].

\section{Realization Paths of Property Tax Reform of China}

\subsection{Enhance Informatization Level of Property Tax Collection}

The first thing the government should do is to make strict control of the real estate registration, increase the transparency of the property management and avoid some bad phenomena. Then encourage property management units to actively use modern information technology to manage, check the basic information of real estate people seriously, and then will be archived and classified carefully the information into the computer, and the implementation of network management, timely 
update of personal property information, to ensure that the needs of departments can query to the relevant property of the latest they obtained permission information. The reform of real estate tax must be progressively promoted based on the basic information on the basic information of residential property, so the following work should be done. Continue to promote the real estate registration information management infrastructure platform, will be scattered in the real estate data integration, land tax, urban construction and other departments, the formation of a national real estate registration database, and through the information according to the law of mutual sharing, build the real estate tax information management system nationwide, improve the collection efficiency, prevent the loss of tax. In the form of legislation to establish and perfect the property declaration system, clear the taxpayer reporting obligations and reporting standards, in the real estate construction, purchase, renovation, property transfer and other matters when truthfully declare, and the declaration of information and real estate tax information management system interface integration, improve the integrity and accuracy of data base. To create the real tax, online tax, tax levy three-in-one mobile comprehensive management platform, improve the tax online, mobile tax service quality and efficiency, enhance the publicity and guidance of pretax and after-tax equity maintenance efforts, provide a free choice of tax declaration and tax payment inquiries and convenient payment vouchers for the taxpayers, improve the tax taxpayers experience, improve taxpayer compliance with tax law.

\subsection{Establish Evaluation Mechanism of Property Tax Price}

Local departments should refine the tax rate of real estate, for example, there should be two different charging methods for land ownership and non-ownership of land. Different types of houses are used for different calculation methods. There should be different taxable methods for houses with different methods of use. The tax department should use modern information technology to do a good job in house supervision and management, to avoid the phenomenon of air conditioning, type conversion and so on. The establishment of a perfect property price evaluation mechanism is mainly from the following aspects. First, we should make a clear assessment of the subject. The establishment of an independent real estate assessment agency under the guidance of local governments is more reliable than the social assessment and tax authorities. Property tax assessment agencies and tax departments and real estate management authority level and to establish a common linkage mechanism, both to ensure the tax collection and administration, real estate management and evaluation work independently of each other, mutual supervision, and fair and transparent cooperation and ensure assessment. Secondly, we should improve the evaluation method. The world's real estate valuation methods include three methods: the market price comparison method, the replacement cost method and the income present value method, which are applicable to different properties of real estate, respectively. The tax authorities in tax assessment, according to the different taxable property evaluation methods, the evaluation results can not only consider the economic fluctuations and inflation, but also can adjust dynamically with the economic cycle to improve the accuracy of the assessment value of property, real property tax burden to ensure fair. Finally, it is necessary to establish a dispute resolution mechanism. The local government should standardize the process of dealing with the dispute of the real estate tax base.

\subsection{Strengthen Publicity Degree of Property Tax Levy}

From the current situation, many taxpayers do not know the contents of the real estate tax reform. They insist on the existing idea that reform will touch their interests, or do not know the specific content of the real estate tax reform. The collection of property tax in our country is mainly based on the way that the owner of the house is declared. If the taxpayers do not understand the relevant laws and regulations, it may lead to the exclusion of laws and regulations. The local government should do a good job of the property tax propaganda, so that the taxpayers are willing to actively cooperate with the work of the staff. In China, we should strengthen the propaganda of property tax and the old were satisfied for the tax authorities to the guidance, the taxpayer consciousness, the serious loss of tax revenue, with the real estate tax propaganda, the use of media at all levels, to take the people popular 
forms, pay more attention to the pertinence and effectiveness of tax propaganda, widely publicize the kind of real estate levy, let people understand their tax obligations, know that they should pay all the taxes way. At the same time, on the existing tax payment platform, we can add fast payment channels such as bank transfer and property tax on the existing tax payment platform. In addition, the use of real estate income helps to enhance taxpayers' awareness of tax payment, such as the use of property tax revenues to build local affordable housing or affordable housing, or for improving urban infrastructure. At the same time, the government should disclose the income and expenditure of the property tax to the taxpayer, while making clear the use of income to the taxpayer. In Chongqing and Shanghai's property tax reform, two cities have clearly defined the use of property tax revenues, but there is no real disclosure mechanism of real estate tax revenues and expenditures.

\subsection{Extend Pilot Project of Property Tax Reform}

In the long run, the real estate tax reform will be promoted in a timely manner, and the tax surface will be gradually expanded. The expansion of the real estate tax pilot can first consider the eastern developed areas and the western provincial capital cities, and then consider other two or three-line cities. From the view of the implementation of the property tax in China, there are only two pilot projects in Shanghai and Chongqing. From the practice of tax levied on real estate in more than 130 countries and regions, the property tax is owned by the individual residents of the housing generally levied, while Shanghai, Chongqing pilot collection was limited to urban housing, therefore should be the property tax levy to expand the scope of the nationwide. If only the first and second tier pilot concentration, the real estate funds will flow to the less developed cities of the real estate market, so that the real estate market in some areas will develop abnormally and will form a mismatch between the real estate development and the real estate market. Therefore, in the process of promoting the real estate tax, the first and second line cities should be gradually covered by the three or four-line cities. At the same time, we should ensure that both the increment and the stock are in the tax area. Only the incremental room is included in the scope of tax, which is beneficial to the expansion of the tax base. Objectively, the property tax can increase the tax burden of the high-income class with multiple suites or upscale housing. The payment scope of the stock room can promote the realization of the tax fairness and the income distribution of the tax regulation. It can also help to increase the supply of the second-hand housing market, and reduce the unreasonable fluctuations brought by the reform to the real estate market. If the tax and fee are collected, the combination of property and land, as a unified collection object, is easy to collect and manage, and can reduce the cost.

\section{Conclusions}

The development of our country's economy and society has provided the background for the reform of the property tax. The reform of the current property tax is an inevitable requirement for the development of China's social and economic development to a certain stage. The goal of real estate tax reform should be to reshape the income structure and income model of local government, and provide a stable and lasting source of revenue for local government. Governments at all levels should closely contact the actual conditions of the country and carefully design the property tax system to give full play to the function of the property tax.

\section{References}

[1] Wei Fang. International Experience of Real Estate Tax Reform and the Situation of China [J]. Reformation \& Strategy, 2016, 32(5): 146-149.

[2] Ouyang Tianjian. On the Value Orientation and Breaking down of Obstacles of Property Tax Reform [J]. Taxation and Economy, 2017(5): 74-81.

[3] Feng Haibo, Liu Yongzheng. Property Tax Reform in China: Multiple Policy Objectives and Constraints [J]. Finance \& Trade Economics, 2011(6): 24-30+136.

[4] Hua Wei, Gong Teng. Reform Thinkings and Policy Proposals of Property Tax Reform in Development Vision [J]. Reform of Economic System, 2015(2): 26-30. 